\title{
Disentangling Climate and Disturbance Effects on Regional Vegetation Greening Trends
}

\author{
Kristen D. Emmett, ${ }^{1 *}$ Katherine M. Renwick, ${ }^{1,2}$ and Benjamin Poulter ${ }^{3}$
}

\begin{abstract}
${ }^{1}$ Department of Ecology, Montana State University, P.O. Box 173460, Bozeman, Montana 59717-3460, USA; ${ }^{2}$ U.S. Forest Service Region 1, 26 Fort Missoula Rd., Missoula, Montana 59804, USA; ${ }^{3}$ Biospheric Sciences Laboratory, Mail Code 618, NASA Goddard Space Flight Center, Greenbelt, Maryland 20771, USA
\end{abstract}

\begin{abstract}
Productivity of northern latitude forests is an important driver of the terrestrial carbon cycle and is already responding to climate change. Studies of the satellite-derived Normalized Difference Vegetation Index (NDVI) for northern latitudes indicate recent changes in plant productivity. These detected greening and browning trends are often attributed to a lengthening of the growing season from warming temperatures. Yet, disturbance-recovery dynamics are strong drivers of productivity and can mask direct effects of climate change. Here, we analyze $1-\mathrm{km}$ resolution NDVI data from 1989 to 2014 for the northern latitude forests of the Greater Yellowstone Ecosystem for changes in plant productivity to address the following questions: (1) To what degree has greening taken place in the GYE over the past three decades? and (2)
\end{abstract}

Received 7 May 2018; accepted 21 September 2018;

published online 5 November 2018

Electronic supplementary material: The online version of this article (https://doi.org/10.1007/s10021-018-0309-2) contains supplementary material, which is available to authorized users.

Author Contributions KE conceived of and designed the study, performed the research and analysis, and wrote the paper. KR contributed to the design of the study, modeling approaches, and writing of the paper. BP contributed to the conception and design of the study, modeling approaches, and writing of the paper.

*Corresponding author; e-mail: kristen.emmett@montana.edu
What is the relative importance of disturbance and climate in explaining NDVI trends? We found that the spatial extents of statistically significant productivity trends were limited to local greening and browning areas. Disturbance history, predominately fire disturbance, was a major driver of these detected NDVI trends. After accounting for fire-, insect-, and human-caused disturbances, increasing productivity trends remained. Productivity of northern latitude forests is generally considered temperature-limited; yet, we found that precipitation was a key driver of greening in the GYE.

Key words: plant productivity; NDVI; climate change; disturbance; fire; Greater Yellowstone Ecosystem; northern latitude forests; boreal climate.

\section{INTRODUCTION}

Increases in photosynthetic activity detected in northern latitudes are often attributed to a lengthening of the growing season from warming temperatures (Myneni and others 1997; Tucker and others 2001; Nemani and others 2003; Zhu and others 2013). Evidence suggests anthropogenic warming is also lengthening the fire season, especially in northern latitudes and resulting in increased forest fire area (Flannigan and others 2013; Abatzoglou and Williams 2016). Since wildland fire plays a major role in temperate and boreal forest 
dynamics, research on the recent changes in photosynthetic activity must consider disturbance recovery and potential changes in disturbance dynamics (Bond-Lamberty and others 2007; SullaMenashe and others 2018). Understanding vegetation dynamics in northern latitudes can aid in anticipating vulnerability of forests to climate change and impacts on terrestrial carbon cycling (Pan and others 2011; Le Quéré and others 2017). The increased availability of satellite-derived observations of Normalized Difference Vegetation Index (NDVI), Leaf Area Index (LAI), and other vegetation indices has led to many recent global and regional studies of plant productivity (Zhu and others 2013, 2016; Potter 2015; Ju and Masek 2016; Rafique and others 2016; Sulla-Menashe and others 2018). Yet, the spatial variability in changes in plant productivity and its drivers are not well understood (Wang and others 2011; Zhu and others 2016).

Plant growth in northern latitudes is considered primarily limited by temperature and the length of the growing season (Whittaker 1975; Churkina and Running 1998). Evidence of spring time warming in the northern hemisphere is well documented and associated with detected increases in photosynthetic activity, or vegetation "greening" trends (Myneni and others 1997; Tucker and others 2001; Zhou 2001; Nemani and others 2003; Wang and others 2011; Xu and others 2013). For the northern hemisphere, the growing season onset is estimated to be 1.1-3.3 days per decade earlier (Wolkovich and others 2012). However, changes in summer precipitation and increases in water vapor pressure deficit (VPD) were associated with decreases in photosynthetic activity, or vegetation "browning" trends (Nemani and others 2003; Angert and others 2005; Piao and others 2011; Zhu and others 2013). Vegetation responses are also dependent on the bioclimatic context. Warming can cause greening trends in ecosystems that are not water limited, while also causing lowered productivity in drier areas where plants experience increased water stress (Sulla-Menashe and others 2018). These findings and recent tree-ring research support the idea that with warming temperatures, presumed temperature-limited boreal vegetation dynamics are becoming limited by other climatic factors (Angert and others 2005; D'Arrigo and others 2008, 2009; Williams and others 2011).

In contrast to these direct climatic drivers, growing evidence suggests that detected changes in plant productivity can also be attributed to disturbance recovery, especially post-fire regeneration (Wang and others 2011; Ju and Masek 2016; Sulla-
Menashe and others 2018). Ju and Masek (2016) found that most of the greening and browning trends in areas of the eastern boreal forests of Alaska and Canada were related to the fire history. In a follow-up study, Sulla-Menashe and others (2018) determined that fire effects explained the magnitude and direction of NDVI changes, with results dependent on the stage of the disturbancesuccession cycle: greening trends were detected in areas that were regenerating after older fires (prior to 1990), whereas recently burned areas displayed browning trends (Sulla-Menashe and others 2018). Increases in the extent and severity of forest insect outbreaks, including mountain pine beetle (Dendroctonus ponderosae), are attributed to warming temperatures that expand suitable habitat and increase population growth for insects (Logan and others 2010; Coops and others 2012; Weed and others 2013). A severe mortality event following an outbreak can affect productivity for decades (Weed and others 2013). Extensive human-caused disturbances, including logging, also affect productivity trends (Zhu and others 2016). As with fire, for insect- and human-caused disturbances, detections of browning or greening trends depend on the time since the event and the productivity of secondary vegetation (Hicke and others 2012; Zhu and others 2016). Herbaceous vegetation initially dominates after high mortality disturbance events until the newly established tree seedlings grow to dominate the canopy. Because NDVI measures the overall amount of light absorbed and reflected by vegetation, it will indicate recovery of any vegetation cover after a disturbance, capturing the initial recovery of herbaceous vegetation with less sensitivity to later successional changes in forest structure (Franks and others 2013). Invasion by opportunistic exotic herbaceous species post-disturbance would also be detected as "early" recovery in NDVI.

Many studies evidence the rapid regeneration of forests post-disturbance in the U.S. Rocky Mountain forests of the Greater Yellowstone Ecosystem (GYE) (Turner and others 2004, 2016; Kashian and others 2005, 2013; Zhao and others 2016). Within the GYE, productivity and biomass increased rapidly following the large fires of 1988 (Turner and others 2004, 2016). In a 300-year chronosequence Kashian and others (2013) found that carbon accumulation recovered to $80 \%$ of pre-fire carbon storage in only 50 years. Harvested areas in the region recovered even more quickly $(50-90 \%$ forest spectral recovery) than burned areas $(<40 \%$ forest spectral recovery) since the 1980s (Zhao and others 2016). However, forest regeneration rates 
can vary widely, with post-fire stem density varying from zero to $344,067 \mathrm{stems} \mathrm{ha}^{-1} 24$-years postfire (Turner and others 2004). After accounting for differences in density, Turner and others (2004) found above-ground net primary productivity decreased with increasing elevation, primarily due to differences in climate. In a study of mountain pine beetles effects on forest productivity in the GYE, Romme and others (1986) found that productivity recovered to pre-outbreak levels in only 1115 years, mostly due to increased growth in the understory. In Douglas fir-dominated forests in the GYE, understory cover was $24 \%$ greater in areas affected by high mortality bark beetle events 45 years prior than compared to undisturbed sites due to greater forb and grass cover (Griffin and Turner 2012).

The detection of local greening and browning areas is dependent on the spatial resolution of satellite data used for the study. Regional studies of recent changes in plant productivity show that trends are heterogeneous across landscapes, with some local greening, browning, and areas without a detectable change (Stow and others 2007; Forkel and others 2013; Sulla-Menashe and others 2018). In a comparison of a Local Area Coverage (1-km resolution) to a Global Area Coverage $(\sim 8-\mathrm{km}$ resolution) NDVI dataset, many greening locations were lost in the coarser resolution dataset (Stow and others 2007). A study using $30-\mathrm{m}$ resolution Landsat NDVI data also shows discrepancies in trend detection compared to 8-km AVHRR (Advanced Very High Resolution Radiometer) NDVI dataset (Ju and Masek 2016). In addition, gridded climate datasets, used as covariates to explain greening trends, are interpolated from weather station data that are only available at moderate spatial resolutions $(800 \mathrm{~m}, \mathrm{l}$ or $4 \mathrm{~km})$.

Here we investigate potential greening trends and their drivers in an analysis of recent NDVI trends in the Greater Yellowstone Ecosystem (GYE) of the U.S. northern Rocky Mountains, a large intact, fire-prone temperate forested ecosystem. Our analyses addressed the following questions: (1) To what degree has greening taken place in the GYE over the past three decades? and (2) What is the relative importance of disturbance and climate in explaining NDVI trends? To address these questions, we analyzed 25 years (1989-2014) of vegetation greening (increasing NDVI) and browning (decreasing NDVI) within the GYE using l-km AVHRR NDVI Composites and compared detected NDVI trends to meteorological data at the same resolution, while using Landsat $30-\mathrm{m}$ resolution data to more precisely attribute disturbance histo- ries (Eidenshink 1992, 2006; Goward and others 2015; Thornton and others 2017).

\section{Study Area}

The Greater Yellowstone Ecosystem (GYE) is considered one of the most intact ecosystems in the contiguous USA and encompasses parts of four national forests and two national parks (Yellowstone and Grand Teton National Park) (Parmenter and others 2003) (Figure 1). The climate of the GYE is highly influenced by the U.S. northern Rocky Mountain topography, with over $70 \%$ of the region at or above $1800 \mathrm{~m}$ (calculated from elevation data: Lehner and others 2008). Although ecologically considered a predominately temperate biome (according to Olson and others (2001) world map), three Köppen-Geiger climate classifications describe the majority of the GYE: boreal warm summer on the western side (36\% of the GYE), boreal cool summer in the central more mountainous terrain $(32 \%)$, and on the eastern side due to the rain shadow effect, arid cold steppe $(28 \%)$ (calculated from Köppen-Geiger data: (Kottek and others 2006).

In western North America, cold winters and dry summers colimit vegetation productivity (Churkina and Running 1998; Nemani and others 2003). Within the GYE winters are long and harsh, with the growing season as short as two months in higher elevations and further limited by summer drying (Despain 1990). Fire also impacts vegetation patterns, especially in the GYE (Whitlock and others 2003). The historical range of variation of fire disturbance in the GYE is dependent on the vegetation type, climate, and elevation (Schoennagel and others 2004). Subalpine forests occupying boreal cool summer areas are characterized by infrequent (fire-return intervals of 150-300 years) high-severity fires (Romme and Despain 1989; Higuera and others 2010). Lodgepole pine (Pinus contorta) dominates much of the subalpine, with subalpine fir (Abies lasiocarpa) and Engelmann spruce (Picea engelmannii) as the late seral species, and whitebark pine (Pinus albicaulis) dominating at higher elevations. Mid-elevation mixed conifer forests consisting of predominately Douglas-fir (Pseudotsuga menziesii), with lodgepole pine, aspen (Populus tremuloides), and limber pine (Pinus flexilis), are characterized by a boreal warm summer climate and mixed-severity fire regimes, with infrequent high- and low-severity fires (Schoennagel and others 2004). Lower-elevation sagebrush steppe and shrublands are characterized by an arid cold climate with fire-return intervals ranging from 


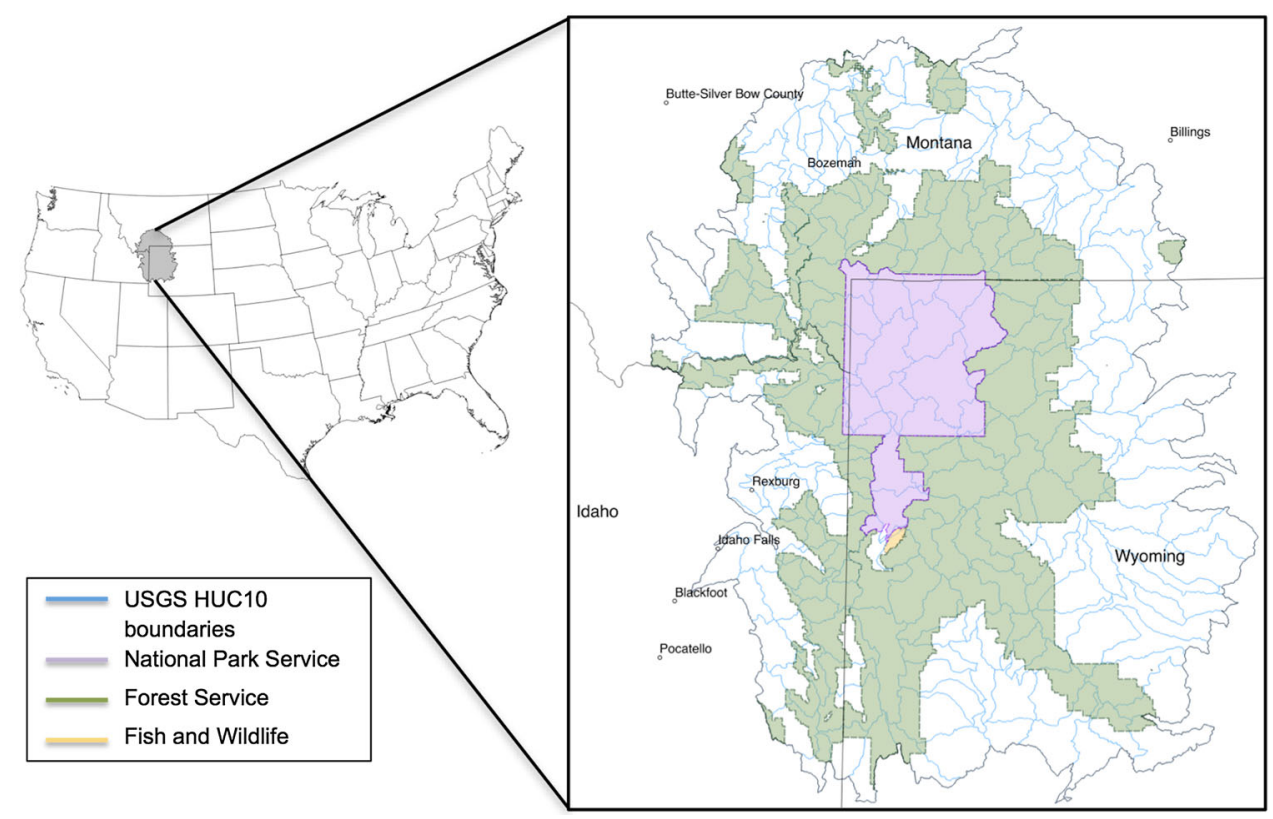

Figure 1. Map of the Greater Yellowstone Ecosystem (GYE) with the study area boundary, U.S. Geological Survey watershed boundaries, and administrative boundaries.

decades to centuries (Whisenant 1990; Bukowski and Baker 2013).

Analysis of gridded climate datasets for the GYE indicates annual temperatures have already increased by $0.02^{\circ} \mathrm{C} \mathrm{y}^{-1}$ from 1928 to 2010 for the region (Chang and Hansen 2015). Despite annual precipitation increasing $0.48 \mathrm{~mm} \mathrm{y}^{-1}(0.8 \%)$ for the same time period (Chang and Hansen 2015), stream discharge decreased, especially during summer months in the GYE (Leppi and others 2012). Leppi and others (2012) explain this paradox by suggesting air temperatures and evapotranspiration rates were stronger drivers of summer stream discharge than precipitation implying increased plant water stress via increases in VPD. Future climate change is expected to shift vegetation growth in northern latitude forests from being temperature to precipitation limited and drastically increase fire severity, fire occurrence, and area burned (Westerling and others 2011; Williams and others 2011).

\section{Data ANd Methods}

For this study we identified the boundaries of GYE based on 10-digit hydrologic units as defined by the USGS Watershed Boundary Dataset (Figure 1). NDVI and covariate datasets were clipped to the GYE boundary and analyses carried out in the World Geodetic System (WGS 84) coordinate reference system. All analyses were carried out using the $\mathrm{R}$ statistical program version 3.4.3 ( $\mathrm{R}$ Core Team 2017) or by using QGIS geoprocessing tools (QGIS Development Team).

\section{Satellite-Derived Vegetation Index}

To track changes in vegetation productivity, we used remotely sensed NDVI data. NDVI datasets derived from AVHRR sensors are the most widely used proxy for observing temporal and spatial changes in terrestrial plant productivity and its response to climate (Running 1990; Pettorelli and others 2005; Beck and others 2011). Satellite sensors measure solar radiation reflected by vegetation and NDVI is calculated from the red (RED, 0.58$0.68 \mu \mathrm{m}$ ) and near-infrared (NIR, 0.725-1.1 $\mu \mathrm{m}$ ) reflected light channels (Tucker 1979; Running 1990; Myneni and others 1995) using the formula in equation 1 :

$$
\mathrm{NDVI}=(\mathrm{NIR}-\mathrm{RED}) /(\mathrm{NIR}+\mathrm{RED})
$$

The chlorophyll in plants absorbs visible light including the red light spectrum and the mesophyll leaf tissue reflects near-infrared light in relation to plant water status (Myneni and others 1995). Thereby, generally the more dense the vegetation the greater the difference between near-infrared light reflected and visible light reflected, since the proportions of both the visible light absorbed and the near-infrared light reflected are greater. NDVI values range from -1 to +1 ; values near zero 
indicate sparse vegetation; and values near +1 indicate dense vegetation (Tucker 1979; Running 1990). Whereas single NDVI measures serve as "snapshots" of forest cover, analysis of changes in NDVI over time can indicate changes in productivity.

The U.S. Geological Survey's (USGS) Earth Resources Observation and Science (EROS) Center used daily observations from Advanced Very High Resolution Radiometer (AVHRR) on National Oceanic and Atmospheric Administration (NOAA) satellites 11 (1989-1994), 14 (1995-2000), 16 (2001-2003), 17 (2004-2009), 18 (2010-2011), and 19 (2012-2014) to produce biweekly composites of maximum NDVI (Eidenshink 1992, 2006). Time variant calibration coefficients for intra- and inter-sensor prelaunch and/or postlaunch calibration were derived using a piecewise linear fit of observations over desert, ocean or cloud observations areas (Vermote and Kaufman 1995; Kaufmann and others 2000). The USGS created the maximum NDVI biweekly composites for the conterminous USA from 1989 to 2015 at $1-\mathrm{km}$ resolution (Eidenshink 1992, 2006).

We used the USGS EROS NDVI biweekly composites (data available from the U.S. Geological Survey), because we were interested in investigating moderate spatial resolution $(1 \mathrm{~km})$ landscape heterogeneity. The benefit of using a higher-resolution dataset is that localized areas of greening can be easily detected that may be missed in coarser datasets (Stow and others 2007). Data of each year were checked for missing, incomplete, or contaminated biweekly composites (from http://lpdaac.usg s.gov) (Figure 2). Gaps were infilled by values from a fitted harmonic sinusoidal model (Verbesselt and others 2010). We created monthly maximums by weighting the biweekly NDVI composites by the number of days they covered within a particular calendar month. Monthly NDVI maximums were used to detect seasonal and annual trends to reduce the influence of incomplete or missing biweekly data. Maximum NDVI value compositing is a common preprocessing technique to "unmask the vegetation signal" by reducing cloud contamination, shadow effects, and water-vapor effects (Holben 1986; Myneni and others 1995). Annual maximum and integrated NDVI were calculated from the monthly maximum NDVI values. Breakpoint analysis on the NDVI time series was completed for each pixel in the GYE to test for artifacts of satellite sensor changes using the "breakpoints" function in the "strucchange" $\mathrm{R}$ package (Zeileis and others 2002, 2003; Bai and Perron 2003); no systematic breaks were detected in the time series.
NDVI saturates in high biomass areas, but this was not an issue in the region since values over the saturation point of 0.9 NDVI (Huete and others 2002) accounted for $0.015 \%$ of the dataset.

\section{Disturbance, Meteorological, and Land Cover Data}

Disturbance, meteorological, and land cover datasets were considered as potential covariates in both filtering the NDVI dataset for spatial analysis and statistical modeling of NDVI trends (Appendix D: Table D1 lists all variables considered). Only three different disturbance agents were considered: fire, insect, and human, because of a lack of comprehensive datasets for other disturbance types. Fire occurrence and severity came from the USGS Monitoring Trends in Burn Severity (MTBS) dataset, a Landsat-based compilation of annual fire information from 1984 through 2015 for the USA (Eidenshink and others 2007). MTBS data has complete coverage of all public and private lands using consistent methodology (Dennison and Brewer 2014). We used the 30-m resolution burn severity mosaic gridded spatial dataset or rasters to identify burn areas in the GYE (MTBS Project (USDA Forest Service/U.S. Geological Survey)).

Data on insect disturbance came from the U.S. Forest Service's Insect and Disease Aerial Detection Surveys (ADS), which provides a semiquantitative assessment of annual bark beetle outbreak area boundaries from 1970 to 2014 for areas flown in the GYE. The USDA Forest Service Forest Health Protection Program and its partners created and provided the ADS data maps from visual assessment from aircrafts. About $80 \%$ of the GYE was flown as a part of the ADS. ADS polygons were combined from USFS Regions 1, 2, and 4 and transformed into a $30-\mathrm{m}$ resolution raster, re-projected, and masked to forested areas.

History of human-caused forest disturbance was derived from the North American Forest Dynamics (NAFD) products. We used the NAFD-NEX timeintegrated map from Landsat images for the conterminous USA from 1986 to 2010 (Goward and others 2015). At 30-m resolution, the map classifies pixels as water, non-forest, "undisturbed" forest, outside of study area, or "disturbance" with associated year. The Vegetation Change Tracker forest change analysis algorithm analyzes each Landsat image to create spectral indices and track the spectral trajectory for each pixel to produce a forest disturbance map (Huang and others 2010). Human-caused forest disturbance was considered as 


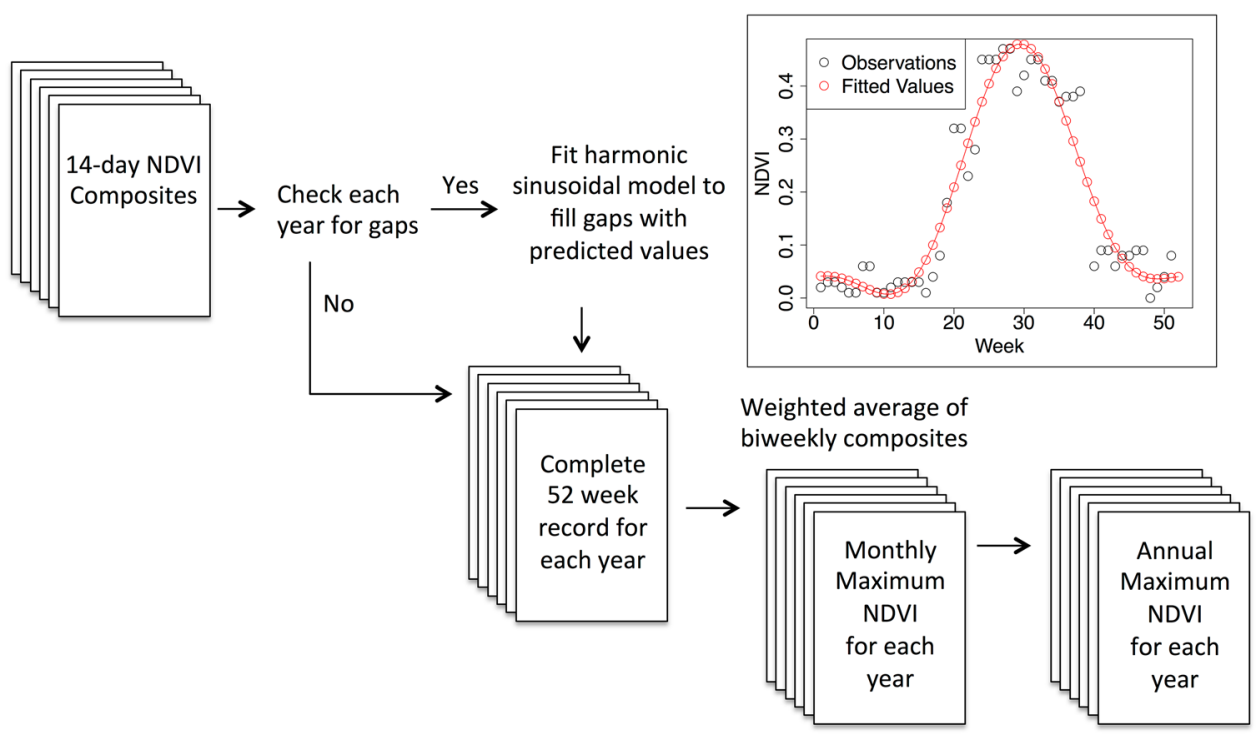

Figure 2. Flowchart of NDVI data processing.

the residual of NAFD data filtered by the MTBS fire data and the ADS bark beetle disturbance data.

To reconcile the spatial resolution differences between our disturbance data $(30 \mathrm{~m})$ and other datasets $(1 \mathrm{~km})$, we performed a percent disturbance threshold sensitivity analysis (details in Appendix $\mathrm{C}$ ), and $30 \%$ threshold was selected to resample the $30-\mathrm{m}$ resolution disturbance data to $1 \mathrm{~km}$ using the "raster" package in R (Hijmans 2015). Fire, bark beetle, and human disturbance 1$\mathrm{km}$ resolution raster layers were then used to mask NDVI trends. For the empirical modeling, the three disturbance datasets were combined to create three explanatory variables: if disturbed, years since disturbance (since 2014), and percent of $1-\mathrm{km}$ pixel disturbed. The created combined disturbance dataset is shown in Appendix C: Figures C1 and C2.

For meteorological covariates, we used $1-\mathrm{km}$ gridded monthly Daymet V3.0 temperature, precipitation, shortwave radiation, vapor pressure, and snow water equivalent datasets produced by Oak Ridge National Laboratory (Thornton and others 2017). The more recent TopoWx v 1.2.0 ("Topography Weather") 800-m gridded temperature dataset was also used to compare results with Daymet (Oyler and others 2014). Monthly data were used to calculate mean annual, mean seasonal, delta annual, and delta seasonal variables using CDO functions (CDO 2015). Daily minimum $\left(T_{\min }\right)$ and maximum temperature $\left(T_{\max }\right)$ data were used to calculate annual aggregated growing degree days (AGDD) as:

$$
\mathrm{AGDD}=\sum_{n=1}^{D} \max \left\{\left(\frac{T_{\max }+T_{\min }}{2}-T_{\text {base }}\right), 0\right\}
$$

where base temperature ( $\left.T_{\text {base }}\right)$ equals $5^{\circ} \mathrm{C}$ and $D$ is the number of days in the year. VPD was calculated using monthly mean/min temperature and vapor pressure data following the American Society of Civil Engineers standardized equations (Walter and others 2005). The re-analyzed Köppen-Geiger climate classifications which are based on vegetative types, precipitation, and air temperature to produce a world map with 31 climate classes at 5-arc-min resolution, were also considered as covariates (Kottek and others 2006). We did not account for increased carbon dioxide in this study and suggest this is an important driver of plant productivity to test using process-based modeling.

Land cover-type data layers were used to filter NDVI trends to limit spatial analysis to only natural vegetation. The National Land Cover Database 2001 (NLCD 2001, 2011 Edition) categorizes land cover for the USA into 16 categories based on a decision tree classification of 2001 Landsat satellite data (Homer and others 2007). The NLCD 2001 data were resampled from $30-\mathrm{m}$ to $1-\mathrm{km}$ resolution using the Resample process with the Majority technique in ArcGIS 10.3.1 (ESRI 2016). For filtering NDVI trends, the data were then reclassified into two classes including "Natural Vegetation" and an "Other" using the ArcGIS Spatial Analysis tool (Appendix B: Table B1). 


\section{NDVI Trend Analysis}

NDVI trend slope estimates were calculated using a linear least squares regression for each pixel within the GYE using Climate Data Operators (CDO 2015). Using annual aggregated time series has been shown to perform better than removing seasonal cycles in a time series to overcome the adverse effects of inter-annual variability in NDVI time series data on trend estimation performance and produces Tau values that range -1 to 1 (Forkel and others 2013). Thereby, NDVI trend slope estimates were calculated from the annual maximum time series and also calculated using integrated NDVI (Appendix A). The two-sided Mann-Kendall test was used to evaluate the significance of monotonic trends in NDVI (Mann 1945). The Mann-Kendall trend test corrected for autocorrelation is commonly used for analyzing meteorological time series as an alternative to linear regression tests because Mann-Kendall does not require a normal distribution of the data and accounts for temporal autocorrelation (Hamed and Ramachandra Rao 1998; de Beurs and Henebry 2004, 2010). We conducted Mann-Kendall tests using the "gimms" $\mathrm{R}$ package (Pinzon and Tucker 2014, 2016) and used a $p<0.05$ significance level threshold.

To isolate the influence of human land use and disturbance, individual pixel NDVI trends were summarized for the GYE before and after filtering out pixels that had land cover layers that were not natural vegetation (using NLCD data), burned since 1984 (using MTBS data), areas affected by bark beetles (using ADS data), and logged stands (using NAFD data) using functions from the "raster" $\mathrm{R}$ package (Hijmans 2015). NDVI trends were compared across different vegetation types with pixels classified based on NLCD categories using an ANOVA with a post-hoc Tukey's Honest Significant Difference method using the "stats" R package ( $\mathrm{R}$ Core Team 2017).

\section{Empirical Modeling}

Linear regression models were fit using a suite of environmental variables to explain maximum annual NDVI trend slopes. We created a training dataset from a random sample of pixels within the GYE comprising $50 \%$ of the total, resulting in a sample size of 61,162 pixels. The remaining $50 \%$ of the data were reserved to evaluate how effectively the selected model explains NDVI. We used linear regression to model maximum annual NDVI trend (hereafter NDVI trend) as a function of the meteorological, topographic, and disturbance history explanatory variables listed in Appendix D: Table D1. Each explanatory variable was standardized by subtracting their mean from each value and then dividing by their standard deviation. Due to the short growing season within the GYE and the susceptibility of volcanic soils to summer drying, summer abiotic factors heavily influence plant growth and were thereby the focus of presented analysis, with summer considered as the months of June, July, and August (JJA). To better represent disturbance, it was included as two continuous variables: percent of pixel disturbed (Perc Dist) and years since disturbance since 2014 (YSD), and one binary variable: if observed disturbance ( $>0 \%$, If Dist) during the time period 1984-2014. Both continuous variables were included in the models paired with the if disturbed binary, so for example the years since disturbance component was only used to estimate the response for pixels that were disturbed during the time period analyzed.

To check for linear and nonlinear multicollinearity issues among potential covariate variables, a matrix of calculated correlation estimates and scatter plots were plotted using the "pairs. panels" function from the "psych" R package (Revelle 2016). Covariates were then reduced to those that were less strongly correlated $(<0.75$ of the correlation coefficient) and after exploratory analyses of the different explanatory variables. All seasonal and annual meteorological variables were considered, and the variable with the highest explanatory power was selected for use in the analysis (for example, mean summer precipitation for precipitation). Individual linear regression models were fit, coefficient estimates plotted, and sums of squares $F$-tests calculated to test the importance of the different explanatory variables using the "stats" R package (R Core Team 2017). In addition, models of combinations of explanatory variables were fit and compared to determine the model that explained the highest percentage of the variance in NDVI slope based on adjusted $R$ squared values. A semivariogram was created from the residuals of the fitted selected model to check for remaining spatial autocorrelation. AIC values were compared for all of the possible model combinations using the variables in the selected model and to the mean-only model (using dredge() from "MuMIn" R package; Bartoń 2016). 


\section{Results}

\section{Greening and Browning in the GYE}

A mean greening trend of $+0.0033 \mathrm{NDVI} / \mathrm{yr}$ $(p<0.05)$ was detected in annual maximum NDVI using the USGS EROS NDVI dataset from 1989 to 2014 , for $26.5 \%$ of pixels within the GYE (Table 1). A mean browning trend of $-0.0035 \mathrm{NDVI} / \mathrm{yr}$ $(p<0.05)$ was detected in annual maximum NDVI for $6.2 \%$ of GYE pixels (Table 1 ). The variance in annual maximum NDVI was 0.015. Analysis of growing season integrated NDVI showed similar trends (Appendix A: Table Al). Annual maximum NDVI was used for further analysis since all values were observations, not fitted values. Removing pixels with land cover other than natural vegetation reduced the detected greening trend spatial extent by $32 \%$, to $17.9 \%$ of the GYE, and the detected browning spatial extent by $13 \%$, to $5.4 \%$ of the GYE (Table 1). The highest concentration of pixels with statistically significant increasing trends in NDVI (greening trends) was in central GYE within Yellowstone National Park (Figure 3A) and to the west in the Caribou-Targhee National Forest. Decreasing trends in NDVI (browning trends) were detected sporadically on the eastern half of the GYE predominately within Shoshone National Forest, with a few localized areas in the southeast within
Bridger-Teton National Forest and Shoshone National Forest (Figure 3A).

The response in NDVI within different vegetation types varied widely, with areas of greening and browning within each vegetation type (Figure 4). Comparison of the mean NDVI trends between vegetation types indicated unique responses for all categories except for mixed forest, which categorized only a few pixels in the GYE based on NLCD. The shrub/scrub, evergreen forest, and grassland/ herbaceous land cover classes describe over $90 \%$ of the GYE. Evergreen forest had a mean greening response (+0.001 SD 0.002), whereas shrub/scrub areas showed a weak mean greening response $(+0.0002$ SD 0.002$)$ and grassland/herbaceous areas showed a weak mean browning response (0.0004 SD 0.002).

\section{Spatial Patterns of NDVI Trends and Disturbance}

Filtering the NDVI trends in the natural vegetation raster for areas that were disturbed removed 38\% of the greening pixels and $33 \%$ of the browning pixels (Table 1). Of the disturbance variables considered, removing pixels within burned areas caused the largest reduction in both the detected greening annual trend in maximum NDVI

Table 1. Trends in Maximum Annual NDVI for All Pixels in the GYE, Pixels with NDVI Trends that are Statistically Significant Mann-Kendall Tau $(p<0.05)$, and Pixels with Natural Vegetation

\begin{tabular}{|c|c|c|c|c|}
\hline Data & Mean trend & NDVI change/decade & Trend SD & Portion of GYE $(\%)$ \\
\hline \multicolumn{5}{|c|}{ Entire GYE (114,106 $1 \mathrm{~km}^{2}$ pixels) } \\
\hline All & 0.0004 & 0.0037 & 0.0024 & 100 \\
\hline Greening & 0.0019 & 0.0193 & 0.0016 & 57.5 \\
\hline Browning & -0.0017 & -0.0173 & 0.0014 & 42.5 \\
\hline \multicolumn{5}{|c|}{ Pixels with statistically significant trend $(p<0.05)$} \\
\hline All & +0.0017 & +0.0170 & 0.0033 & 26.5 \\
\hline Greening & 0.0033 & 0.0329 & 0.0017 & 20.4 \\
\hline Browning & -0.0035 & -0.0354 & 0.0016 & 6.2 \\
\hline \multicolumn{5}{|c|}{ Natural vegetation } \\
\hline Greening & 0.0033 & 0.0332 & 0.0017 & 17.9 \\
\hline Browning & -0.0035 & -0.0348 & 0.0016 & 5.4 \\
\hline \multicolumn{5}{|c|}{ After fire disturbed areas removed } \\
\hline Greening & 0.0029 & 0.0293 & 0.0012 & 14.0 \\
\hline Browning & -0.0033 & -0.0331 & 0.0015 & 4.4 \\
\hline \multicolumn{5}{|c|}{ After human disturbed areas removed } \\
\hline Greening & 0.0029 & 0.0285 & 0.0011 & 12.5 \\
\hline Browning & -0.0033 & -0.0332 & 0.0015 & 4.2 \\
\hline \multicolumn{5}{|c|}{ After insect disturbed areas removed } \\
\hline Greening & 0.0029 & 0.0288 & 0.0012 & 11.1 \\
\hline Browning & -0.0034 & -0.0338 & 0.0015 & 3.6 \\
\hline
\end{tabular}




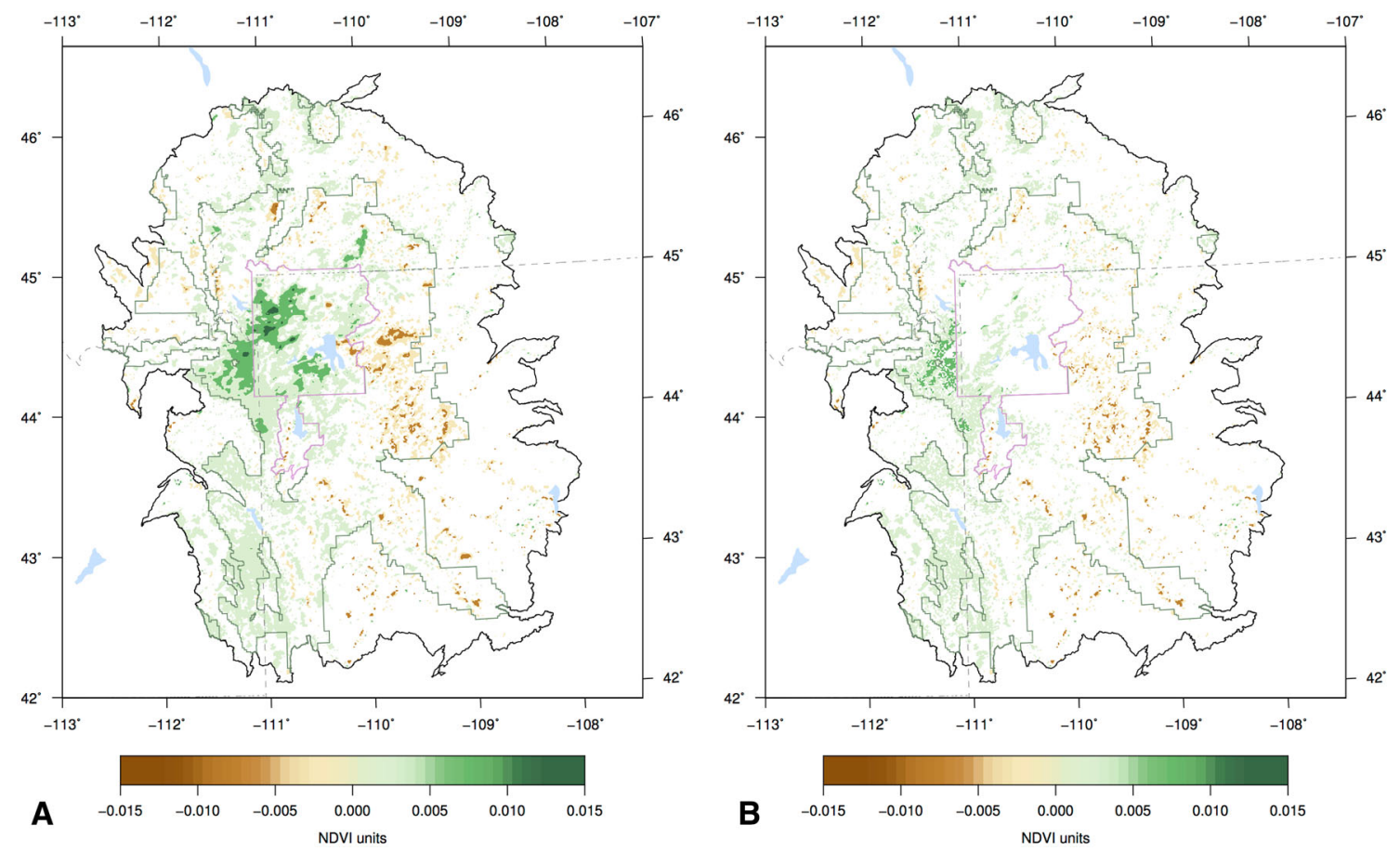

Figure 3. A Trends in maximum annual NDVI for natural vegetation within the GYE from 1989 to 2014 . B Trends in maximum annual NDVI after removing burned, bark beetle affected, and logged areas. Figure shows only pixels with NDVI trends that are statistically significant (Mann-Kendall Tau $p<0.05$ ).

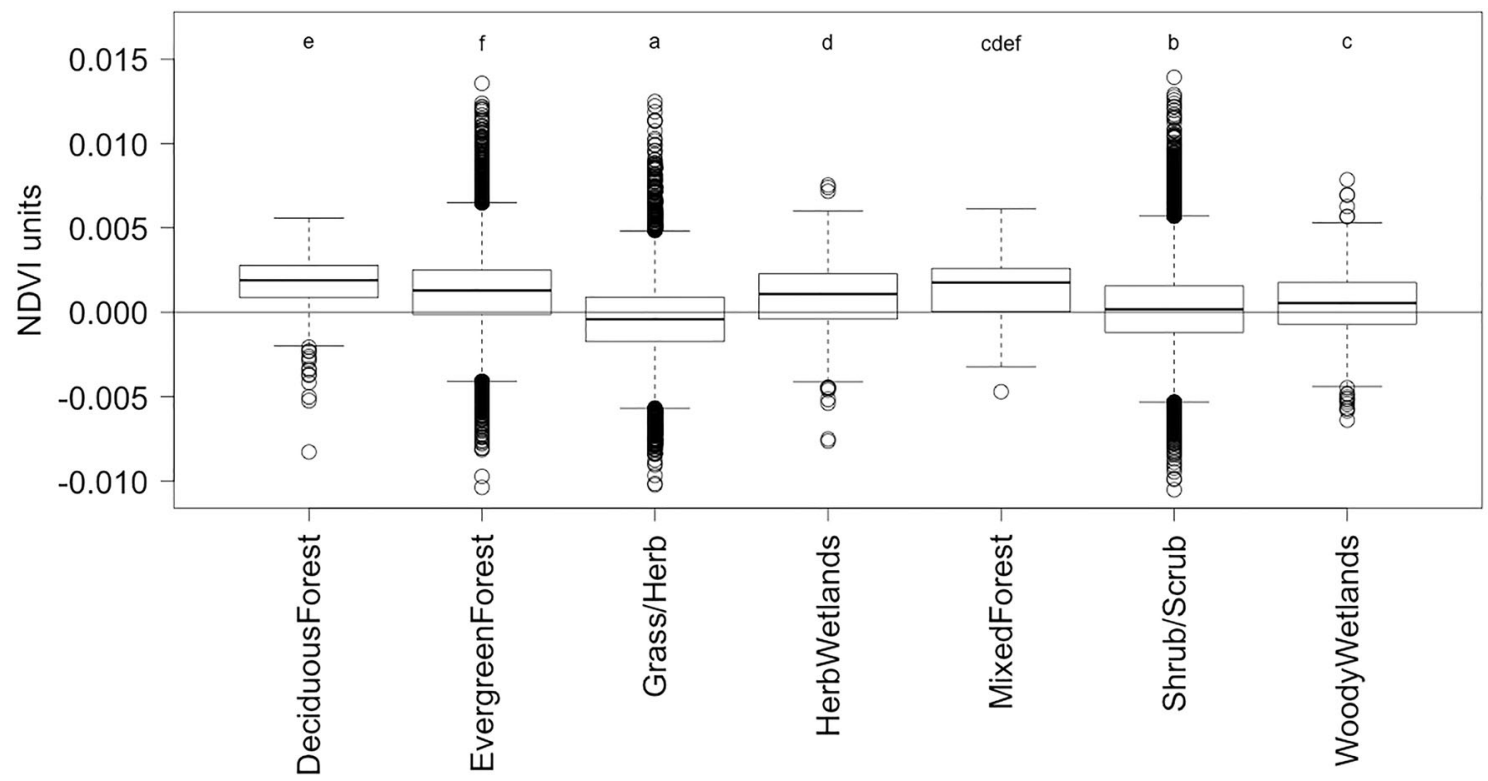

Figure 4. Trends in maximum annual NDVI by vegetation type defined by NLCD categories. Letters represent results of Tukey's honest significance difference comparison of mean NDVI trends between vegetation types.

$(+0.0029 / \mathrm{yr})$ and the fraction of pixels considered (reduced by 3.9 to $14.0 \%$ of the GYE) (Table 1). Removing human and insect disturbed areas reduced the fraction of greening pixels by another 1.5 and $1.4 \%$, respectively, without affecting the magnitude of the trend.

Removing burned pixels reduced greening area extent by $65 \%$ within the National Park boundaries 
and removed the strong browning areas to the east within the National Forest (Figure 3B). Removing human disturbed areas reduced greening areas west of the parks and removing insect disturbed areas reduced browning areas to the east. After filtering out all disturbances, most of the remaining of the greening area $(75 \%)$ was within National Forest designations, with $30 \%$ within CaribouTarghee National Forest (Figure 3B).

\section{The Role of Disturbance and Climate in Explaining NDVI Trends}

Coefficient estimates for the separate models fits of climate, growing season length, and disturbance variables with NDVI trends aided in identifying key drivers of change in NDVI (Figure 5). The main effects of change in temperature and mean temperature for both mean annual (MA) and summer (JJA, for the months of summer: June, July, and August) variables showed negative relationships with NDVI trends, while their interaction effect was positive (Figure 5). Aggregated growing degree days showed a negative relationship with NDVI trends. For the precipitation models, the main effects of change in precipitation and mean precipitation for both annual and summer variables showed positive relationships with NDVI trends, whereas their interaction effect was negative. VPD for both MA and JJA showed positive relationships with NDVI trends, while change in VPD and the interaction coefficients were negative. The disturbance model showed a positive relationship between disturbance terms and NDVI trends. The largest coefficient estimates were for change in summer precipitation (Delta JJA Precip) and disturbance (YSD : Perc Dist). Plotted density curves of covariate distributions for all GYE pixels and greening cells show associations with NDVI trends (Figure 6). The average greening pixel had a higher mean summer precipitation compared to all the GYE (Figure 6A). Although most of the GYE had decreasing mean summer precipitation, greening pixels experience less drying (Figure 6B). Greening pixels were limited in their temperature range, with fewer pixels in the hotter temperature range compared to all of the GYE (Figure 6C). Greening pixels distribution also had a higher kurtosis in change in mean annual temperature (Figure 6D).

The most parsimonious explanatory model explained $29 \%$ of the variation in NDVI slope $\left(r^{2}=0.29, \quad F=2505, \quad p<0.0001\right)$. Exploratory statistical analysis was performed on all the considered variables, but issues with independence required selecting between collinear variables such as summer precipitation and VPD or mean annual temperature and AGDD. The explanatory model included mean summer precipitation (JJA Precip), change in mean summer precipitation (Delta JJA Precip), mean annual temperature (MA Temp), change in mean annual temperature (Delta MA Temp), years since disturbance (YSD), percent of

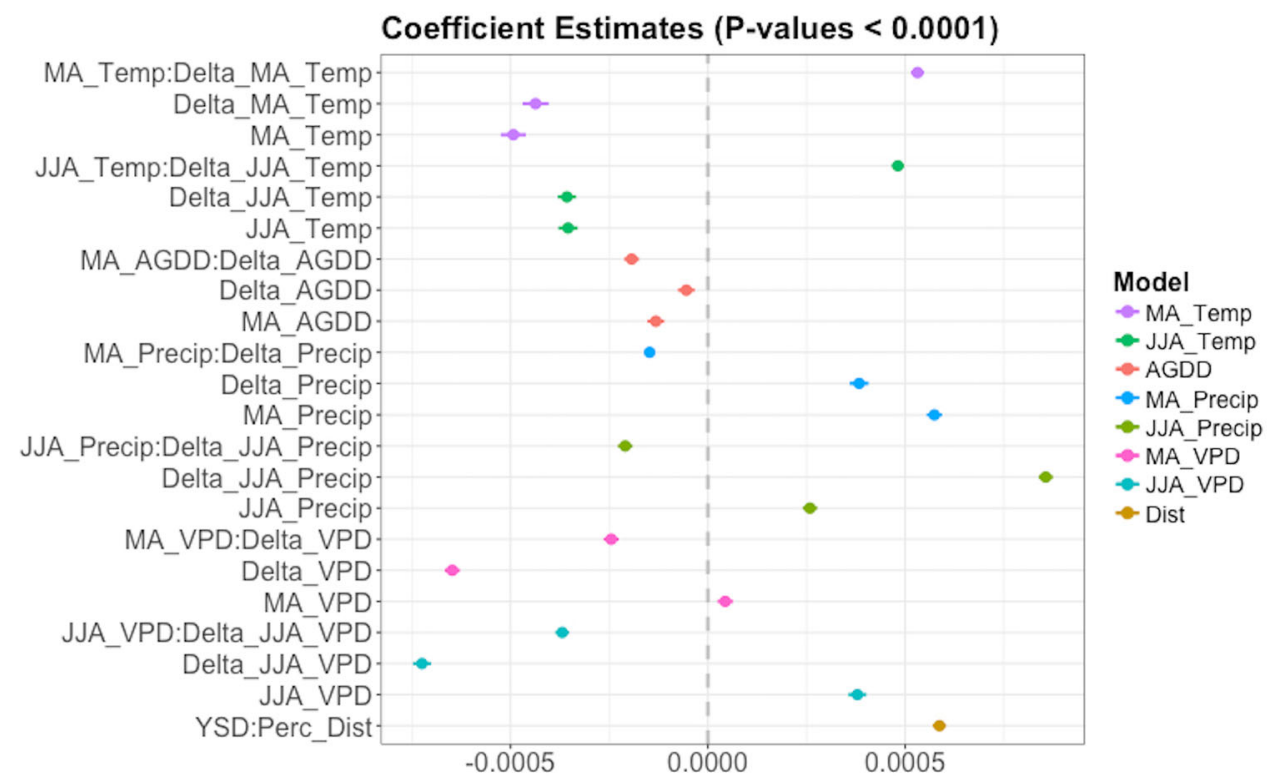

Figure 5. Coefficient estimates of standardized explanatory variables on NDVI trends from separate model fits. Where $J J A$ is the months of summer: June, July, August, $V P D$ vapor pressure deficit, $M A$ mean annual, $A G D D$ annual growing degree days, Temp temperature, Precip precipitation, Dist disturbance, YSD years since disturbance, Perc Dist percent disturbance. 

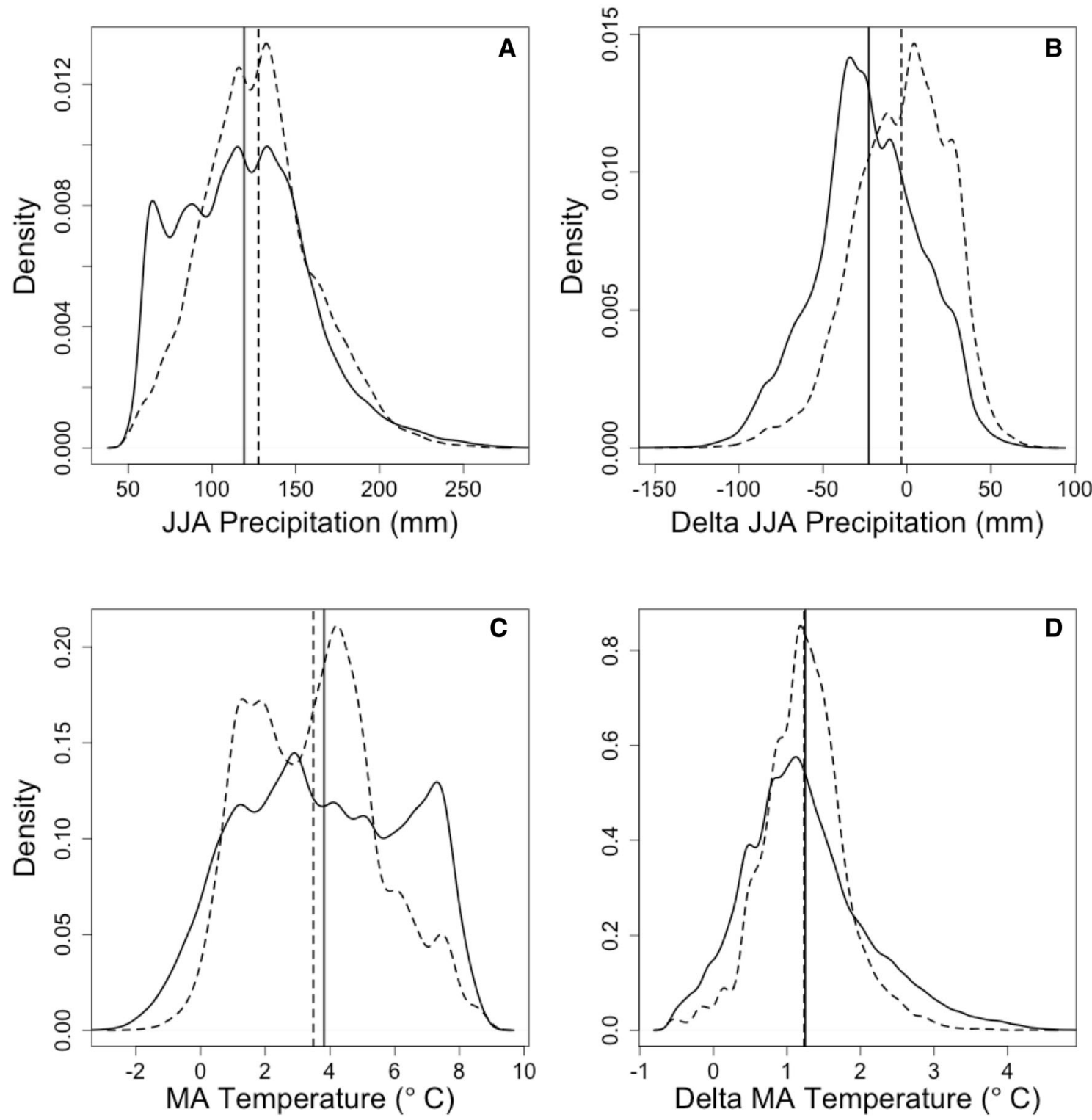

Figure 6. Density curves for meteorological covariates used to fit statistical model to explain NDVI trends: A mean annual summer (JJA) precipitation, B delta JJA precipitation, C mean annual (MA) temperature, and D delta MA temperature. Solid lines show densities for all GYE pixels and dashed lines show densities for greening pixels $(p<0.05)$ with vertical lines marking the respective mean values.

pixel disturbed (Perc Dist), and if disturbance observed (If Dist) with several interactions. Table 2 provides units and data sources for these explanatory variables. The estimated coefficients and $95 \%$ CI for each explanatory variable in the model are shown in Figure 7. The second most parsimonious model dropped the interaction term between change in mean summer precipitation and delta mean summer precipitation and had a delta AIC of 652, providing support for including this interaction term (Table 3 ).
Increases in summer precipitation had relatively the strongest positive relationship with NDVI slopes (Figure $7,+0.0006\left(\right.$ SE $\left.9 \times 10^{-6}\right)$ ). Mean summer precipitation also had a positive relationship $\left(+0.00035\left(\mathrm{SE} 1 \times 10^{-5}\right)\right)$, meaning that wetter sites had a larger greening effect. The interaction between summer precipitation and change in precipitation had a negative relationship (JJA Precip * Delta JJA Precip, $-0.00022\left(\right.$ SE $\left.8 \times 10^{-6}\right)$ ). Areas in the GYE that were relatively dry had increased NDVI trends with increased summer pre- 
Table 2. Explanatory Variables for the Top Explanatory Model of NDVI Trends

\begin{tabular}{lll}
\hline Predictor & Abbreviations & Units \\
\hline Meteorological (annual mean) & & millimeters \\
Summer precipitation & JJA Precip & millimeters \\
Delta summer precipitation & Delta JJA Precip & degrees Celsius \\
Annual temperature & MA Temp & degrees Celsius \\
Delta annual temperature & Delta MA Temp & \\
Disturbance history & & percent of l km pixel disturbed \\
Percent disturbed & Perc Dist & years since disturbance \\
Years since disturbance & YSD & 0 (False) or l (True) \\
If disturbance observed & If Dist &
\end{tabular}

Meteorological data are Daymet V3.0 (Thornton and others 2017). Disturbance history data are a combination of three disturbance datasets: North American Forest Dynamics (Goward and others 2015), Monitoring Trends in Burn Severity (Eidenshink and others 2007), and Arial Detection Surveys (Goward and others 2015). JJA June, July, and August for the months of summer. MA mean annual.

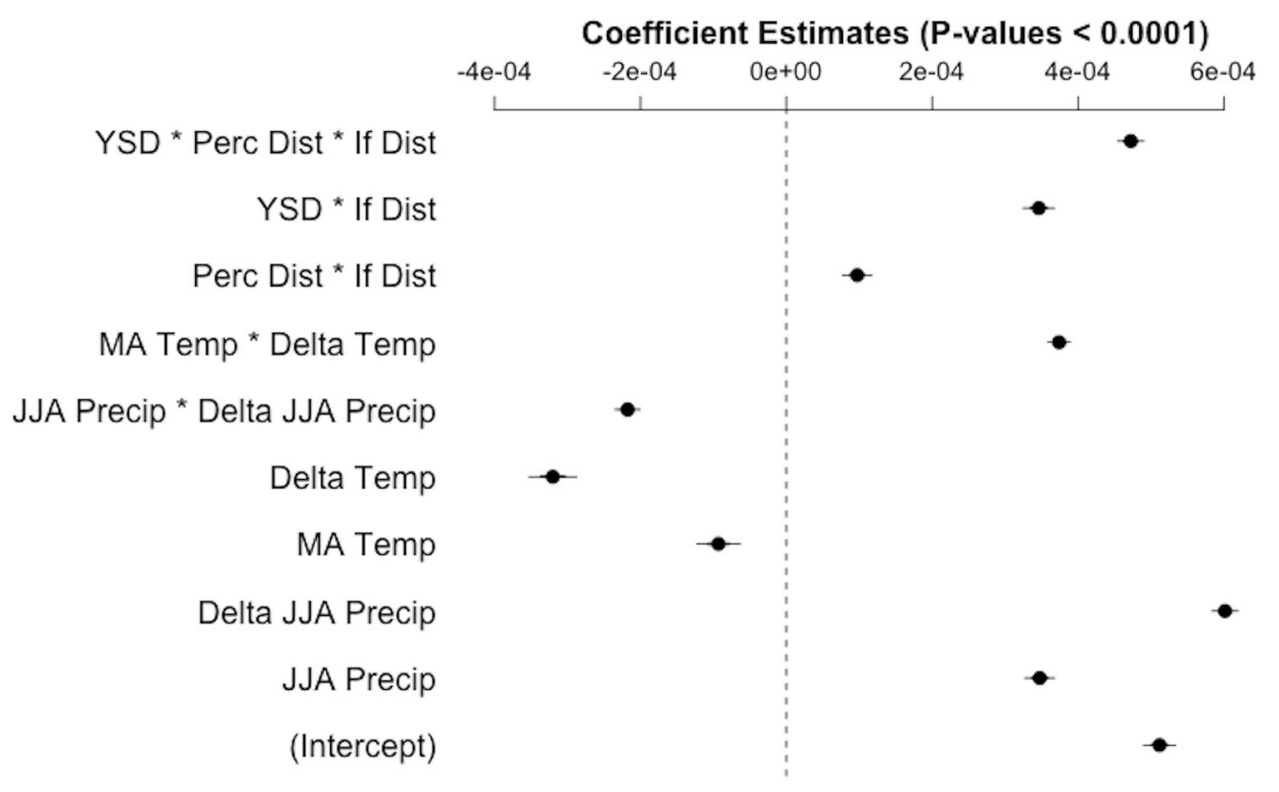

Figure 7. Coefficient estimates of standardized explanatory variables on NDVI trends from the top explanatory model. Where $J J A$ is the months of summer: June, July, August, VPD vapor pressure deficit, MA mean annual, $A G D D$ annual growing degree days, Temp temperature, Precip precipitation, Dist disturbance, YSD years since disturbance, and Perc Dist percent disturbance.

Table 3. AIC Values for the Top Model Compared to the "Next Best" and Mean-only Model

\begin{tabular}{lrr}
\hline Model & $d f$ & Delta AIC \\
\hline Top model & 11 & 0 \\
Next best & 10 & 652 \\
Mean only & 2 & 19,767 \\
\hline
\end{tabular}

cipitation compared to wetter areas (Figure 8B). Areas in the GYE that were relatively wet had increased NDVI trends with decreased summer precipitation while NDVI trends decreased for dry areas experiencing the same reduction in summer precipitation (Figure $8 \mathrm{~B}$ ).

The second strongest positive relationship was between NDVI slopes and the disturbance threeway interaction (YSD * Perc Dist * If Dist, $+0.00047\left(\right.$ SE $\left.\left.9 \times 10^{-6}\right)\right)$, with disturbed pixels associated with higher NDVI slopes or greening trends. Disturbed cells that had longer to recover (higher YSD) and were more disturbed (higher Perc Dist) were associated with higher NDVI slopes (Figure 8A).

Higher mean annual temperature and higher change in mean annual temperature had a negative association with NDVI slopes. The interaction be- 

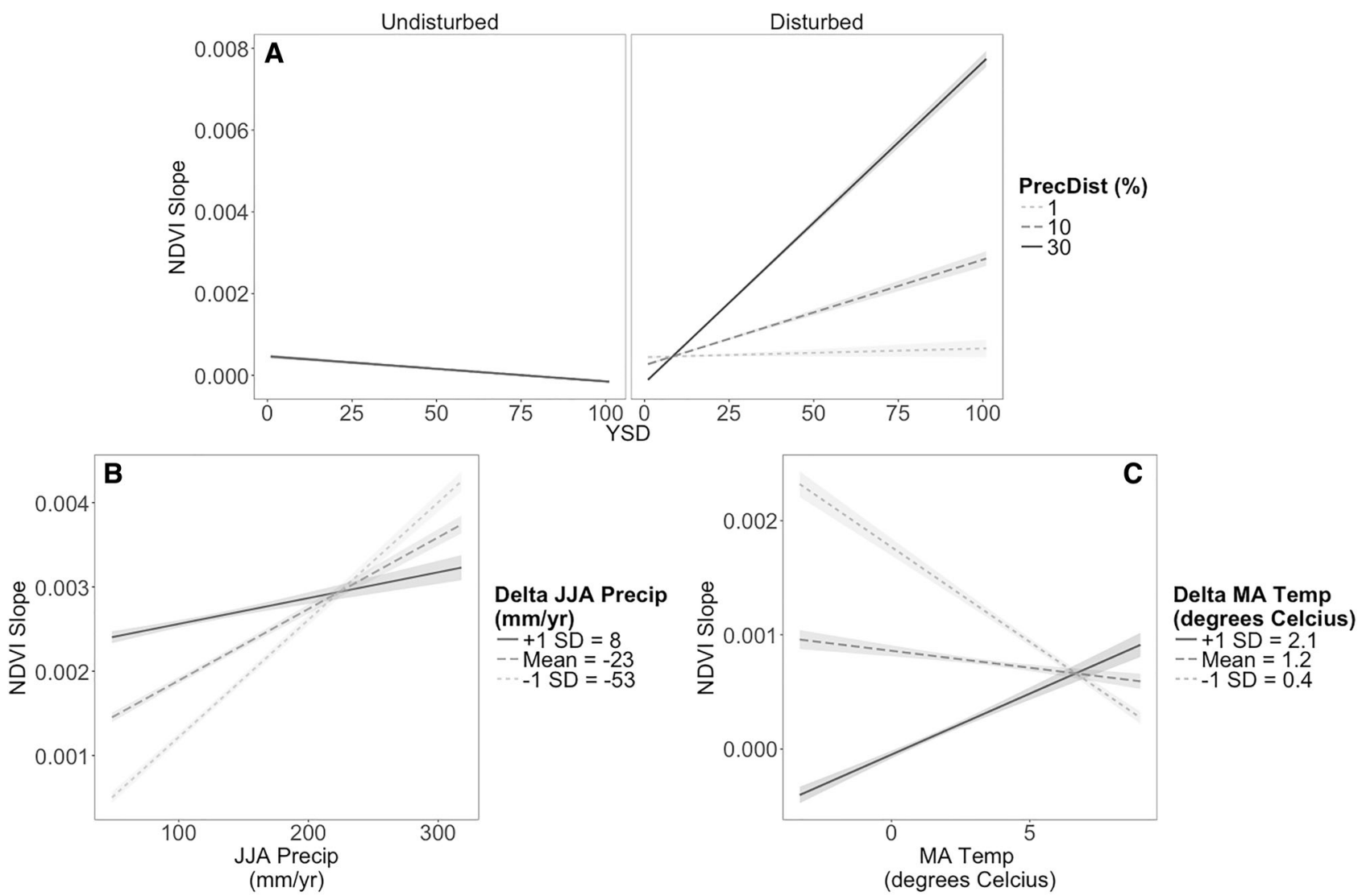

Figure 8. Interaction effect plots on NDVI slopes between A years since disturbance (YSD) and percent disturbed (Perc Dist) (right), NDVI slope estimates for undisturbed pixels also shown (left), B mean annual summer precipitation (JJA Precip) and delta mean annual summer precipitation (Delta JJA Precip), C mean annual temperature (MA Temp) and delta mean annual temperature (Delta MA Temp).

tween mean annual temperature and change in mean annual temperature had a positive relationship with NDVI slopes (Figure 8C, + 0.00037 (SE $\left.8 \times 10^{-6}\right)$ ). Moderate warming $\left(0-2^{\circ} \mathrm{C}\right)$ for all areas was associated with greening trends. Areas experiencing a greater increase in annual temperature $\left(>2^{\circ} \mathrm{C}\right)$ had a browning response in NDVI. Cooler areas were more sensitive to changes in annual temperature than warmer areas of the GYE, with the coolest areas experiencing the most extreme increases in temperature and were associated with lower NDVI slopes than areas with less warming (Figure 8C).

\section{Discussion}

\section{Greening and Browning in the GYE}

Significant greening and browning trends were limited in their spatial extent to only 17.9 and $5.4 \%$ of naturally vegetation areas in the GYE, respectively, with the majority of pixels within the region not showing strong trends during the studied time period of 1989-2014. The order of magnitude difference between the regional average NDVI trend $(+0.0004 \mathrm{NDVI} / \mathrm{yr})$ and the greening/browning localized trends $(+0.0033 \mathrm{NDVI} / \mathrm{yr}, \quad-0.0035$ NDVI/yr, respectively) highlights the importance of analyzing plant productivity at finer spatial resolutions that otherwise are aggregated in coarse scale analyses (for example, Zhu and others 2016). Spatial analysis of NDVI slopes at $1-\mathrm{km}$ resolution also revealed the heterogeneity of plant productivity trends across the GYE. Strong greening trends tended to be in the more moist central and western regions of the GYE within Caribou-Targhee National Forest and Yellowstone National Park, whereas strong browning trends tended to be in the more arid eastern regions of the GYE within Shoshone National Forest and Bridger-Teton National Forest. The fine-grained spatial pattern of productivity is consistent with previous research in Yellowstone National Park (Turner and others 2004, 2016). 
The average NDVI trend across the entire GYE $(+0.0004 \mathrm{NDVI} / \mathrm{yr})$ is of the same sign, and general magnitude of NDVI trends detected in boreal climate regions from global studies (+ 0.00038 NDVI/ yr) (Rafique and others 2016). The magnitude of the detected greening trends, or greening areas in the GYE $(+0.0033 \mathrm{NDVI} / \mathrm{yr}, p<0.05)$ was comparable to trends detected in forests of Canada and Alaska (+ 0.003 NDVI/yr) (Ju and Masek 2016). For detected browning areas in the GYE, the mean trend of $-0.0035 \mathrm{NDVI} / \mathrm{yr}, p<0.05$ was also comparable to detected browning trend values in forests of Canada and Alaska ( -0.002 to -0.004 NDVI/yr) (Ju and Masek 2016).

Comparison of NDVI trends between different vegetation types based on NLCD categories indicated different responses by vegetation type, although the range in responses within each category varied widely. Evergreen forests showed a mean greening response and comprised the areas of strongest detected greening trends in the GYE. In contrast, more of the browning areas were categorized as shrub/scrub or grassland/herbaceous. The broad NLCD categories limit inference can be made from this analysis. For example, "evergreen forests" includes the low, mid, and high elevation forests of the GYE that have unique vegetation compositions and potentially unique responses in NDVI. Although comparison of NDVI responses at the species level is beyond the scope of this paper, it remains an important area of research for illuminating the underlying mechanism of changes in plant productivity.

\section{The Role of Disturbance in Explaining NDVI Trends}

Filtering the NDVI trends in the natural vegetation for areas that were disturbed removed $38 \%$ of the greening pixels and $33 \%$ of the browning pixels, providing evidence for the importance of disturbance in explaining detected changes in plant productivity. Filtering for fire disturbance alone removed $22 \%$ of the areas with greening trends, with human disturbance removing $8 \%$ and bark beetle infestations removing $8 \%$ of the greening trends. Statistical modeling of disturbance effects on NDVI trends showed that disturbed pixels that had longer to recover (higher YSD) and were more disturbed (higher Perc Dist) were associated with higher NDVI slopes or greening trends. Recently disturbed pixels were associated with negative NDVI slopes or browning trends. These results are consistent with studies of rapid post-disturbance recovery in the GYE (Turner and others 2004,
2016; Kashian and others 2005, 2013; Zhao and others 2016) and changes in productivity in northern latitude forests in Alaska and Canada (Ju and Masek 2016; Sulla-Menashe and others 2018) and reinforce the need for considering landscape history in analysis of plant productivity trends. As previously mentioned, recovery of NDVI values post-disturbance is sensitive to herbaceous plant recovery, including potential opportunistic exotic species (for example, Canada thistle (Cirsium arvense) and prickly lettuce (Lactuca serriola) (Turner and others 2008)). Thereby, positive NDVI trends do not indicate whether or not the forest canopy has regenerated specifically nor indicate the composition of native vs. exotic species without further analysis.

\section{The Role of Climate in Explaining NDVI Trends}

While statistical modeling supported the importance of disturbance in explaining greening and browning trends in the GYE, it also provided some evidence for the influence of meteorological variables on NDVI trends. Summer precipitation and annual temperature emerged as the meteorological factors with the strongest influence on NDVI trends. The importance of the interaction between mean summer (JJA) precipitation and change in JJA precipitation demonstrates the importance of the bioclimatic context of climate change. Increases in summer precipitation benefitted areas that were relatively dry. It follows that vegetation in the wetter areas were not water limited and thereby did not benefit from increased summer precipitation. The linear model fit instead suggests reductions in summer precipitation benefitted wetter areas, yet precipitation type (snow vs. rain) or nonlinear effects not represented might explain this result. Previous studies suggest extension of the growing season length and water stress, represented here by AGDD and VPD, respectively, drive plant productivity in the boreal climate region (Angert and others 2005; Boisvenue and Running 2006; D'Arrigo and others 2008; Williams and others 2011). Although both AGDD and VPD showed statistically significant relationships with NDVI trends, temperature and precipitation explained more of the observed trends than these variables.

Increased temperatures in boreal climate regions can facilitate plant growth through an elongated growing season without precipitation limitation (Boisvenue and Running 2006), and this is supported by the location of detected greening trends 
primarily in forests in the boreal climate of western and central GYE. Indeed, process-based model simulations also indicate that warming temperatures will favor positive growth responses for lodgepole pine dominated forests in Yellowstone National Park (Smithwick and others 2009). Yet, the coolest areas in the GYE, the Absaroka Mountain Range and the Wind River Range are also areas that experienced the greatest increase in mean annual temperatures and high-severity mortality due to mountain pine beetle (MacFarlane and others 2013) and were associated with browning trends. Climate warming benefits mountain pine beetles by increasing overwinter survival leading to increased outbreak populations (Bentz and others 1991). MacFarlane and others (2013) used an alternative aerial survey method and found whitebark pine mortality caused by mountain pine beetle to be more widespread than as reported in the Aerial Detection Survey data. Thereby, these detections of browning trends may be interpreted as signals of mountain pine beetle mortality that were not captured in the Aerial Detection Survey data.

Recent studies suggest the decoupling of northern latitude forest growth and warming temperatures, with other factors such as fire disturbance, insect and disease outbreaks, and water stress driving detected trends in forest productivity (Goetz and others 2005). Our results provide further evidence of the important effects of disturbance on productivity trends and the importance of precipitation during the growing season for tree growth. This may suggest that the greening trends previously detected and attributed to warming temperatures and lengthening of the growing season are not spatially consistent across boreal climate zones, nor are these relationships expected to continue under future climate projections. Growing evidence already suggests that tree growth in northern latitudes is being limited by drought stress (Angert and others 2005; D'Arrigo and others 2008, 2009; Williams and others 2011). For undisturbed forests during their study period, Sulla-Menashe and others (2018) found that the direct effects of climate change showed minimal influence on NDVI trends overall, but with varying effects based on local bioclimatic differences. Similarly, we show that the effects of precipitation and temperature changes on forest productivity are highly dependent on the local bioclimatic context, driving the sign and magnitude of detected NDVI trends.

\section{Further Considerations}

Global studies suggest that multiple factors drive productivity trends in northern latitudes (Nemani and others 2003; Zhu and others 2016). Beyond the climatic and disturbance factors explored in this paper, other possible mechanisms for detected increases in NDVI include a fertilization effect from increases in atmospheric carbon dioxide or nitrogen deposition. Increases in atmospheric carbon dioxide are expected to increase plant growth. Global ecosystem modeling simulations suggest carbon dioxide fertilization effects may explain more of the observed greening trends in satellite data than climate (Piao and others 2006; Zhu and others 2016). Although accounting for carbon dioxide fertilization effects was outside the scope of this paper, it remains a potentially important driver of detected NDVI trends. Process-based ecosystem modeling offers an opportunity for testing and quantifying the relative effects of carbon dioxide increases and climate change on plant productivity in the GYE. Increases in nitrogen deposition can also stimulate plant growth. Soils vary within the GYE from nutrient-poor rhyolitic soils of the Yellowstone Caldera to andesitic soils of higher-elevation forests that are higher in nutrients and water holding capacity (Despain 1990). The productivity of lodgepole pine forests on rhyolitic soils is generally considered nitrogen limited (Fahey and others 1985); thereby, increased nitrogen availability could act as a fertilizer. Furthermore, increased annual temperatures and precipitation could stimulate plant growth indirectly through increased soil temperature and moisture facilitating nutrient and water uptake (Reddell and others 1985).

Finally, it is worth noting that the inferences in this study are limited by the temporal extent and quality of the disturbance data. While the NDVI time series was from 1989 to 2014 , the disturbance data did not represent even this discrete time frame. For example, extensive logging occurred in the Caribou-Targhee National Forest between 1950 and 1990 (Parmenter and others 2003), with only logging starting in 1986 and beyond captured in the NAFD disturbance data. The inclusion of U.S. Forest Service forest stand maps could aid in controlling for disturbance more fully in analyses of changes in productivity (Tinker and others 2003). In fact, century-long time scales are required to understand the regrowth legacies of disturbances 
(Williams and others 2016), with carbon stocks and fluxes stabilizing after 100 years in subalpine Rocky Mountain forests (Bradford and others 2008).

Larger and more synchronous fires have occurred during hot and dry periods, suggesting climate is the dominant driver of fire behavior in the region (Balling and others 1992; Morgan and others 2008; Marlon and others 2012). Predicted climate induced changes in the fire return interval in the GYE could drastically alter forest regeneration, from forest extent, species composition, to age-class distribution (Romme and Turner 1991; Westerling and others 2011). Climate warming is also predicted to increase mountain pine beetle outbreaks causing forest die-off (Logan and Powell 2001; Logan and others 2010). With disturbance playing such a significant role in forest dynamics in the GYE and other northern latitude temperate and boreal forests, further research is needed on the interactive effects of temperature, precipitation, and disturbance on forest productivity and how these relationships may change under future climate conditions.

\section{ACKNOWLEDGEMENTS}

We thank Steve Cherry, Dave Roberts, and Mark Greenwood for discussions on statistical approaches. Thank you to Christopher Williams, Huan $\mathrm{Gu}$, and $\mathrm{Yu}$ Zhou for sharing processed ADS and NAFD data and Arjun Adhikari for sharing NLCD. The article was improved by helpful suggestions from Robert Keane, Monica Turner, and Andrew Hansen. The research was supported, in part, by NSF Grant GSS-1461590; Grant No. G15AP00073 from the United States Geological Survey; NSF Graduate Research Fellowship Award No. DGE-1632134; and the Montana Institute on Ecosystems with support from NSF-IIA-1443108 and EPS-1101342.

\section{OPEN ACCESS}

This article is distributed under the terms of the Creative Commons Attribution 4.0 International License (http://creativecommons.org/licenses/by/4.0/), which permits unrestricted use, distribution, and reproduction in any medium, provided you give appropriate credit to the original author(s) and the source, provide a link to the Creative Commons license, and indicate if changes were made.

\section{REFERENCES}

Abatzoglou JT, Williams AP. 2016. Impact of anthropogenic climate change on wildfire across western US forests. Proc Natl Acad Sci 113:11770-5.

Angert A, Biraud S, Bonfils C, Henning CC, Buermann W, Pinzon J, Tucker CJ, Fung I. 2005. Drier summers cancel out the $\mathrm{CO} 2$ uptake enhancement induced by warmer springs. Proc Natl Acad Sci 102:10823-7.

Bai J, Perron P. 2003. Computation and analysis of multiple structural change models. J Appl Econ 18:1-22.

Balling RC, Meyer GA, Wells SG. 1992. Relation of surface climate and burned area in Yellowstone National Park. Agric For Meteorol 60:285-93.

Bartoń K. 2016. MuMIn: Multi-Model Inference. https://cran.rproject.org/package $=$ MuMIn.

Beck HE, McVicar TR, van Dijk AIJM, Schellekens J, de Jeu RAM, Bruijnzeel LA. 2011. Global evaluation of four AVHRRNDVI data sets: intercomparison and assessment against Landsat imagery. Remote Sens Environ 115:2547-63.

Bentz BJ, Logan JA, Amman GD. 1991. Temperature-dependent development of the mountain pine beetle (Coleoptera: Scolytidae) and simulation of its phenology. Can Entomol 123:1083-94.

Boisvenue C, Running SW. 2006. Impacts of climate change on natural forest productivity-evidence since the middle of the 20th century. Glob Change Biol 12:862-82.

Bond-Lamberty B, Peckham SD, Ahl DE, Gower ST. 2007. Fire as the dominant driver of central Canadian boreal forest carbon balance. Nature 450:89-92.

Bradford JB, Birdsey RA, Joyce LA, Ryan MG. 2008. Tree age, disturbance history, and carbon stocks and fluxes in subalpine Rocky Mountain forests. Glob Change Biol 14:2882-97.

Bukowski BE, Baker WL. 2013. Historical fire regimes, reconstructed from land-survey data, led to complexity and fluctuation in sagebrush landscapes. Ecol Appl 23:546-64.

CDO. 2015. Climate Data Operators, CDO version 1.9.3. http:// www.mpimet.mpg.de/cdo.

Chang T, Hansen A. 2015. Historic \& projected climate change in the Greater Yellowstone Ecosystem. Yellowstone Sci 23:14-19.

Churkina G, Running SW. 1998. Contrasting climatic controls on the estimated productivity of global terrestrial biomes. Ecosystems 1:206-15.

Coops NC, Wulder MA, Waring RH. 2012. Modeling lodgepole and jack pine vulnerability to mountain pine beetle expansion into the western Canadian boreal forest. For Ecol Manag 274:161-71.

D'Arrigo R, Wilson R, Liepert B, Cherubini P. 2008. On the 'Divergence Problem' in Northern Forests: a review of the tree-ring evidence and possible causes. Glob Planet Change 60:289-305.

D'Arrigo R, Jacoby G, Buckley B, Sakulich J, Frank D, Wilson R, Curtis A, Anchukaitis K. 2009. Tree growth and inferred temperature variability at the North American Arctic treeline. Glob Planet Change 65:71-82.

de Beurs KM, Henebry GM. 2004. Trend analysis of the pathfinder AVHRR land (PAL) NDVI data for the deserts of central Asia. IEEE Geosci Remote Sens Lett 1:282-6. 
de Beurs KM, Henebry GM. 2010. A land surface phenology assessment of the northern polar regions using MODIS reflectance time series. Can J Remote Sens 36:S87-110.

Dennison P, Brewer S. 2014. Large wildfire trends in the western United States, 1984-2011. Geophys Res Lett 41:2928-33.

Despain DG. 1990. Yellowstone vegetation: consequences of environment and history in a natural setting. Boulder: Roberts Rinehart.

Eidenshink JC. 1992. The 1990 conterminous U.S. AVHRR data set. Photogramm Eng Remote Sens 58:809-13.

Eidenshink J. 2006. A 16-year time series of $1 \mathrm{~km}$ AVHRR satellite data of the conterminous United States and Alaska. Photogramm Eng Remote Sens 72:1027-35.

Eidenshink J, Schwind B, Brewer K, Zhu Z, Quayle B, Howard S. 2007. A project for monitoring trends in fire severity. Fire Ecol 3:3-21.

ESRI. 2016. ArcGIS 10.3.1, Environmental Systems Resource Institute. ArcMap 10.3.1. ESRI, Redlands.

Fahey TJ, Yavitt JB, Pearson JA, Knight DH. 1985. The nitrogen cycle in lodgepole pine forests, southeastern Wyoming. Biogeochemistry 1:257-75.

Flannigan M, Cantin AS, De Groot WJ, Wotton M, Newbery A, Gowman LM. 2013. Global wildland fire season severity in the 21st century. For Ecol Manag 294:54-61.

Forkel M, Carvalhais N, Verbesselt J, Mahecha MD, Neigh CSR, Reichstein M. 2013. Trend change detection in NDVI time series: effects of inter-annual variability and methodology. Remote Sens 5:2113-44.

Franks S, Masek JG, Turner MG. 2013. Monitoring forest regrowth following large scale fire using satellite data: a case study of Yellowstone National Park, USA. Eur J Remote Sens 46:561-9.

Goetz SJ, Bunn AG, Fiske GJ, Houghton RA. 2005. Satelliteobserved photosynthetic trends across boreal North America associated with climate and fire disturbance. Proc Natl Acad Sci 102:13521-5.

Goward SN, Huang C, Zhao F, Schleeweis K, Rishmawi K, Lindsey M, Dungan JL, Michaelis A. 2015. NACP NAFD Project: forest disturbance history from Landsat, 1986-2010. ORNL DAAC, Oak Ridge, Tennessee. https://doi.org/10.3334/ ornldaac/ 1290 .

Griffin JM, Turner MG. 2012. Changes to the N cycle following bark beetle outbreaks in two contrasting conifer forest types. Oecologia 170:551-65.

Hamed KH, Ramachandra Rao A. 1998. A modified MannKendall trend test for autocorrelated data. J Hydrol 204:18296.

Hicke JA, Allen CD, Desai AR, Dietze MC, Hall RJ, Hogg EHT, Kashian DM, Moore D, Raffa KF, Sturrock RN, Vogelmann J. 2012. Effects of biotic disturbances on forest carbon cycling in the United States and Canada. Glob Change Biol 18:7-34.

Higuera PE, Whitlock C, Gage JA. 2010. Linking tree-ring and sediment-charcoal records to reconstruct fire occurrence and area burned in subalpine forests of Yellowstone National Park, USA. Holocene 21:327-41.

Hijmans RJ. 2015. raster: Geographic Data Analysis and Modeling. R package version 2.4-18. https://cran.r-project.or $\mathrm{g} /$ package $=$ raster .

Holben BN. 1986. Characteristics of maximum-value composite images from temporal AVHRR data. Int $\mathrm{J}$ Remote Sens 7:1417-34.
Homer C, Dewitz J, Fry J, Coan M, Hossain N, Larson C, Herold N, McKerrow A, VanDriel JN, Wickham J. 2007. Completion of the 2001 National Land Cover Database for the conterminous United States. Photogramm Eng Remote Sens 73:33741.

Huang C, Goward SN, Masek JG, Thomas N, Zhu Z, Vogelmann JE. 2010. An automated approach for reconstructing recent forest disturbance history using dense Landsat time series stacks. Remote Sens Environ 114:183-98.

Huete A, Didan K, Miura H, Rodriguez EP, Gao X, Ferreira LF. 2002. Overview of the radiometric and biophysical performance of the MODIS vegetation indices. Remote Sens Environ 83:195-213.

Ju J, Masek JG. 2016. The vegetation greenness trend in Canada and US Alaska from 1984-2012 Landsat data. Remote Sens Environ 176:1-16.

Kashian DM, Turner MG, Romme WH, Lorimer CG. 2005. Variability and convergence in stand structural development on a fire-dominated subalpine landscape. Ecology 86:643-54.

Kashian DM, Romme WH, Tinker DB, Turner MG. 2013. Postfire changes in forest carbon storage over a 300-year chronosequence of Pinus contorta-dominated forests. Ecol Monogr 83:49-66.

Kaufmann RK, Zhou L, Knyazikhin Y, Shabanov NV, Tucker CJ. 2000. Effect of orbital drift and sensor changes on the time series of AVHRR vegetation index data. IEEE Trans Geosci Remote Sens 38:2584-97.

Kottek M, Grieser J, Beck C, Rudolf B, Rubel F. 2006. World map of the Köppen-Geiger climate classification updated. Meteorol Z 15:259-63.

Le Quéré C, Andrew RM, Friedlingstein P, Sitch S, Pongratz J, Manning AC, Korsbakken JI, Peters GP, Canadell JG, Jackson RB, Boden TA, Tans PP, Andrews OD, Arora VK, Bakker DCE, Barbero L, Becker M, Betts RA, Bopp L, Chevallier F, Chini LP, Ciais P, Cosca CE, Cross J, Currie K, Gasser T, Harris I, Hauck J, Haverd V, Houghton RA, Hunt CW, Hurtt G, Ilyina T, Jain AK, Kato E, Kautz M, Keeling RF, Klein Goldewijk K, Körtzinger $\mathrm{A}$, Landschützer $\mathrm{P}$, Lefèvre $\mathrm{N}$, Lenton $\mathrm{A}$, Lienert $\mathrm{S}$, Lima I, Lombardozzi D, Metzl N, Millero F, Monteiro PMS, Munro DR, Nabel JEMS, Nakaoka S, Nojiri Y, Padín XA, Peregon A, Pfeil B, Pierrot D, Poulter B, Rehder G, Reimer J, Rödenbeck C, Schwinger J, Séférian R, Skjelvan I, Stocker BD, Tian H, Tilbrook B, van der Laan-Luijkx IT, van der Werf GR, van Heuven S, Viovy N, Vuichard N, Walker AP, Watson AJ, Wiltshire AJ, Zaehle S, Zhu D. 2017. Global Carbon Budget 2017. Earth Syst Sci Data 10:405-48.

Lehner B, Verdin K, Jarvis A. 2008. New global hydrography derived from spaceborne elevation data. Eos 89:93-4.

Leppi JC, DeLuca TH, Harrar SW, Running SW. 2012. Impacts of climate change on August stream discharge in the CentralRocky Mountains. Clim Change 112:997-1014.

Logan JA, Powell JA. 2001. Ghost forests, global warming, and the mountain pine beetle (Coleoptera : Scolytidae). American Entomol 47:160-73.

Logan JA, MacFarlane WW, Willcox L. 2010. Whitebark pine vulnerability to climate-driven mountain pine beetle disturbance in the Greater Yellowstone Region. Ecol Appl 20:895902.

MacFarlane WW, Logan JA, Kern WR. 2013. An innovative aerial assessment of Greater Yellowstone Ecosystem mountain pine beetle-caused whitebark pine mortality. Ecol Appl 23:421-37. 
Mann HB. 1945. Nonparametric tests against trend. Econometrica 13:245-59.

Marlon JR, Bartlein PJ, Gavin DG, Long CJ, Anderson RS, Briles CE, Brown KJ, Colombaroli D, Hallett DJ, Power MJ, Scharf EA, Walsh MK. 2012. Long-term perspective on wildfires in the western USA. Proc Natl Acad Sci 109:E535-43.

Morgan P, Heyerdahl EK, Gibson CE. 2008. Multi-season climate synchronized forest fires throughout the 20th century, Northern Rockies, USA. Ecology 89:717-28.

MTBS Project (USDA Forest Service/U.S. Geological Survey). MTBS Direct Download: Burn Severity Mosaics. (2017, May 1). http://mtbs.gov/data/direct-download [2017, Sept20].

Myneni RB, Hall FG, Sellers PJ, Marshak AL. 1995. Interpretation of spectral vegetation indexes. IEEE Trans Geosci Remote Sens 33:481-6.

Myneni RB, Keeling CD, Tucker CJ, Asrar G, Nemani RR. 1997. Increased plant growth in the northern high latitudes from 1981 to 1991 . Nature 386:698-702.

Nemani RR, Keeling CD, Hashimoto H, Jolly WM, Piper SC, Tucker CJ, Myneni RB, Running SW. 2003. Climate-driven increases in global terrestrial net primary production from 1982 to 1999. Science 300:1560-3.

Olson DM, Dinerstein E, Wikramanayake ED, Burgess ND, Powell GVN, Underwood EC, D'amico JA, Itoua I, Strand HE, Morrison JC, Loucks CJ, Allnutt TF, Ricketts TH, Kura Y, Lamoreux JF, Wettengel WW, Hedao P, Kassem KR. 2001. Terrestrial ecoregions of the world: a new map of life on Earth. Bioscience 51:933-8.

Oyler JW, Ballantyne A, Jencso K, Sweet M, Running SW. 2014. Creating a topoclimatic daily air temperature dataset for the conterminous United States using homogenized station data and remotely sensed land skin temperature. Int J Climatol $35: 2258-79$

Pan Y, Birdsey RA, Fang J, Houghton R, Kauppi PE, Kurz WA, Phillips OL, Shvidenko A, Lewis SL, Canadell JG, Ciais P, Jackson RB, Pacala SW, McGuire AD, Piao S, Rautiainen A, Sitch S, Hayes D. 2011. A large and persistent carbon sink in the world's forests. Science 333:988-93.

Parmenter AW, Hansen A, Kennedy RE, Cohen W, Langner U, Lawrence R, Maxwell B, Gallant A, Aspinall R. 2003. Land use and land cover change in the Greater Yellowstone Ecosystem: 1975-1995. Ecol Appl 13:687-703.

Pettorelli N, Vik JO, Mysterud A, Gaillard JM, Tucker CJ, Stenseth NC. 2005. Using the satellite-derived NDVI to assess ecological responses to environmental change. Trends Ecol Evol 20:503-10.

Piao S, Friedlingstein P, Ciais P, Zhou L, Chen A. 2006. Effect of climate and $\mathrm{CO} 2$ changes on the greening of the Northern Hemisphere over the past two decades. Geophys Res Lett $33: 2-7$.

Piao S, Wang X, Ciais P, Zhu B, Wang T, Liu J. 2011. Changes in satellite-derived vegetation growth trend in temperate and boreal Eurasia from 1982 to 2006. Glob Change Biol 17:322839.

Pinzon JE, Tucker CJ. 2014. A non-stationary 1981-2012 AVHRR NDVI3 g time series. Remote Sens 6:6929-60.

Pinzon JE, Tucker CJ. 2016. A Non-Stationary 1981-2015 AVHRR NDVI3 g.vl Time Series: an update. In preparation for submission to Remote Sensing.

Potter C. 2015. Vegetation cover change in Yellowstone National Park detected using Landsat satellite image analysis. J Biodivers Manag For 4:1-10.
QGIS Development Team. QGIS Geographic Information System. Open Source Geospatial Foundation Project. http://ww W.qgis.org/.

R Core Team. 2017. R: a language and environment for statistical computing. R Foundation for Statistical Computing, Vienna. h ttps://www.r-project.org/.

Rafique R, Zhao F, de Jong R, Zeng N, Asrar G. 2016. Global and regional variability and change in terrestrial ecosystems net primary production and NDVI: a model-data comparison. Remote Sens 8:177.

Reddell P, Bowen GD, Robson AD. 1985. The effects of soil temperature on plant growth, nodulation and nitrogen fixation. New Phytol 101:441-50.

Revelle W. 2016. Psych: procedures for psychological, psychometric, and personality research, Psych version 1.7.8. https://c ran.r-project.org $/$ package $=$ psych.

Romme WH, Despain DG. 1989. Historical perspective on the yellowstone fires of 1988. Bioscience 39:695-9.

Romme WH, Turner MG. 1991. Implications of global climate change for biogeographic patterns in the Greater Yellowstone Ecosystem. Conserv Biol 5:373-86.

Romme WH, Knight DH, Yavitt JB. 1986. Mountain pine beetle outbreaks in the Rocky-Mountains-regulators of primary productivity. Am Nat 127:484-94.

Running SW. 1990. Estimating terrestrial primary productivity by combining remote sensing and ecosystem simulation. In: Hobbs RJ, Mooney HA, Eds. Remote sensing of biosphere functioning. New York: Springer. pp 65-86.

Schoennagel T, Veblen TT, Romme WH. 2004. The interaction of fire, fuels, and climate across Rocky Mountain forests. Bioscience 54:661-76.

Smithwick EAH, Ryan MG, Kashian DM, Romme WH, Tinker DB, Turner MG. 2009. Modeling the effects of fire and climate change on carbon and nitrogen storage in lodgepole pine (Pinus contorta) stands. Glob Change Biol 15:535-48.

Stow D, Petersen A, Hope A, Engstrom R, Coulter L. 2007. Greenness trends of Arctic tundra vegetation in the 1990s: comparison of two NDVI data sets from NOAA AVHRR systems. Int J Remote Sens 28:4807-22.

Sulla-Menashe D, Woodcock CE, Friedl MA. 2018. Canadian boreal forest greening and browning trends: an analysis of biogeographic patterns and the relative roles of disturbance versus climate drivers. Environ Res Lett 13:014007.

Thornton PE, Thornton MM, Mayer BW, Wei Y, Devarakonda R, Vose RS, Cook RB. 2017. Daymet: Daily Surface Weather Data on a 1-km Grid for North America, Version 3. https://doi.org/ 10.3334/ornldaac/1328.

Tinker DB, Romme WH, Despain DG. 2003. Historic range of variability in landscape structure in subalpine forests of the Greater Yellowstone Area, USA. Landsc Ecol 18:427-39.

Tucker CJ. 1979. Red and photographic infrared linear combinations for monitoring vegetation. Remote Sens Environ 8:127-50.

Tucker CJ, Slayback DA, Pinzon JE, Los SO, Myneni RB, Taylor MG. 2001. Higher northern latitude normalized difference vegetation index and growing season trends from 1982 to 1999. Int J Biometeorol 45:184-90.

Turner MG, Tinker DB, Romme WH, Kashian DM, Litton CM. 2004. Landscape patterns of sapling density, leaf area, and aboveground net primary production in postfire lodgepole pine forests, Yellowstone National Park (USA). Ecosystems $7: 751-75$ 
Turner MG, Romme WH, Gardner RH. 2008. Effects of fire size and pattern on early succession in Yellowstone National Park. Ecol Monogr 67:41 1-33.

Turner MG, Whitby TG, Tinker DB, Romme WH. 2016. Twentyfour years after the Yellowstone fires: are postfire lodgepole pine stands converging in structure and function? Ecology 97:1260-73.

Verbesselt J, Hyndman R, Zeileis A, Culvenor D. 2010. Phenological change detection while accounting for abrupt and gradual trends in satellite image time series. Remote Sens Environ 114:2970-80.

Vermote E, Kaufman YJ. 1995. Absolute calibration of AVHRR visible and near-infrared channels using ocean and cloud views. Int J Remote Sens 16:2317-40.

Walter IA, Allen RG, Elliot R, Itenfisu D, Brown P, Jensen ME, Mecham B, Howell Terry A, Synder R, Eching S, Spofford T, Hattendorf M, Martin D, Cuence Richard H, Wright L. 2005. The ASCE standardized reference evapotranspiration equation. Reston, ID: American Society of Civil Engineers.

Wang X, Piao S, Ciais P, Li J, Friedlingstein P, Koven C, Chen A. 2011. Spring temperature change and its implication in the change of vegetation growth in North America from 1982 to 2006. Proc Natl Acad Sci USA 108:1240-5.

Weed AS, Ayres MP, Hicke JA. 2013. Consequences of climate change for biotic disturbances. Ecol Monogr 83:441-70.

Westerling AL, Turner MG, Smithwick EAH, Romme WH, Ryan MG. 2011. Continued warming could transform Greater Yellowstone fire regimes by mid-21st century. Proc Natl Acad Sci USA 108:13165-70.

Whisenant SG. 1990. Changing fire frequencies on Idaho's Snake River plains: ecological and management implications. In: McArthur ED, Romney EM, Smith SD, Tueller PT, Eds. Proceedings-Symposium on cheatgrass invasion, shrub dieoff, and other aspects of shrub biology and management General Technical Report INT-GTR-276. USDA Forest Service, Ogden, pp 4-10.

Whitlock C, Shafer SL, Marlon J. 2003. The role of climate and vegetation change in shaping past and future fire regimes in the northwestern US and the implications for ecosystem management. For Ecol Manag 178:5-21.

Whittaker RH. 1975. Communities and ecosystems. 2nd edn. New York: Macmillan Publishing Co., Inc.

Williams AP, Xu C, McDowell NG. 2011. Who is the new sheriff in town regulating boreal forest growth? Environ Res Lett 6:041004.
Williams CA, Gu H, MacLean R, Masek JG, Collatz GJ. 2016. Disturbance and the carbon balance of US forests: a quantitative review of impacts from harvests, fires, insects, and droughts. Glob Planet Change 143:66-80.

Wolkovich EM, Cook BI, Allen JM, Crimmins TM, Betancourt JL, Travers SE, Pau S, Regetz J, Davies TJ, Kraft NJB, Ault TR, Bolmgren K, Mazer SJ, McCabe GJ, McGill BJ, Parmesan C, Salamin N, Schwartz MD, Cleland EE. 2012. Warming experiments underpredict plant phenological responses to climate change. Nature 485:494-7.

Xu L, Myneni RB, Chapin FS, Callaghan TV, Pinzon JE, Tucker CJ, Zhu Z, Bi J, Ciais P, Tømmervik H, Euskirchen ES, Forbes BC, Piao SL, Anderson BT, Ganguly S, Nemani RR, Goetz SJ, Beck PSA, Bunn AG, Cao C, Stroeve JC. 2013. Temperature and vegetation seasonality diminishment over northern lands. Nat Clim Change 3:581-6.

Zeileis A, Leisch F, Hornik K, Kleiber C. 2002. strucchange: an R package for testing for structural change in linear regression models. J Stat Softw 7:1-38.

Zeileis A, Kleiber C, Walter K, Hornik K. 2003. Testing and dating of structural changes in practice. Comput Stat Data Anal 44:109-23.

Zhao FR, Meng R, Huang C, Zhao M, Zhao FA, Gong P, Yu L, Zhu Z. 2016. Long-term post-disturbance forest recovery in the Greater Yellowstone Ecosystem analyzed using Landsat time series stack. Remote Sens 8:898.

Zhou L. 2001. Variations in northern vegetation activity inferred from satellite data of vegetation index during 1981 to $1999 . \mathrm{J}$ Geophys Res 106:20069-83.

Zhu Z, Bi J, Pan Y, Ganguly S, Anav A, Xu L, Samanta A, Piao S, Nemani RR, Myneni RB. 2013. Global data sets of vegetation leaf area index (LAI) $3 \mathrm{~g}$ and fraction of photosynthetically active radiation (FPAR) $3 \mathrm{~g}$ derived from global inventory modeling and mapping studies (GIMMS) normalized difference vegetation index (NDVI3G) for the period 1981 to 2011. Remote Sens 5:927-48.

Zhu Z, Piao S, Myneni RB, Huang M, Zeng Z, Canadell JG, Ciais P, Sitch S, Friedlingstein P, Arneth A, Cao C, Cheng L, Kato E, Koven C, Li Y, Lian X, Liu Y, Liu R, Mao J, Pan Y, Peng S, Peuelas J, Poulter B, Pugh TAM, Stocker BD, Viovy N, Wang X, Wang Y, Xiao Z, Yang H, Zaehle S, Zeng N. 2016. Greening of the Earth and its drivers. Nat Clim Change 6:791-5. 